\title{
Multi-stage Depressurization Analysis of Subsea Production System Based on LedaFlow Software
}

\author{
Wenfeng Chen, Pengpeng Ju, Xueyuan Wang *, Dong Wang, Feilong Liu \\ Engineering Research \& Design Department, Offshore Oil Engineering Co., Ltd, 300451, Tianjin, China
}

\begin{abstract}
This paper briefly summarizes that during the depressurization operation in subsea pipeline for maintenance or prevention of hydrate formation, because the flare knock-out drum pump is designed for ambient temperature, and cannot deal with the low temperature fluid in the depressurization process. Therefore, the low temperature fluid needs to be heated in the knock-out drum to meet the temperature requirement of pump. In order to avoid the volume of low temperature fluid exceeding the surge volume of the flare knock-out drum, the concept of multi stage depressurization is innovatively proposed in this paper, which meets both the requirements of pump temperature and the surge volume of flare drum. Taking a gas field project in the South China Sea as an example, the simulation analysis of depressurization temperature and pressure is carried out by using different size of the blowdown valve. It provides a good reference for the similar project in future.
\end{abstract}

\section{Introduction}

Subsea production systems (SPS) are widely used in deep-water and marginal oilfield development[1]. The water depth of a gas field project in the South China Sea is $1500 \mathrm{~m}$, using the subsea production system and semisubmersible platform (SEMI) development program, the natural gas is exported after drying and dehydration treatment in SEMI, and the condensate oil is stored in SEMI for regular export after qualified dehydration treatment. The SPS consists of seven production wells (W1-W7), with relatively scattered well locations, using three subsea manifold (E1 E3) and double subsea pipeline development scheme. Oil \& gas wells output pipelines are connected to subsea manifold through jumpers, and production fluid are connected to SEMI for processing[2]. The schematic diagram is shown in Figure 1.

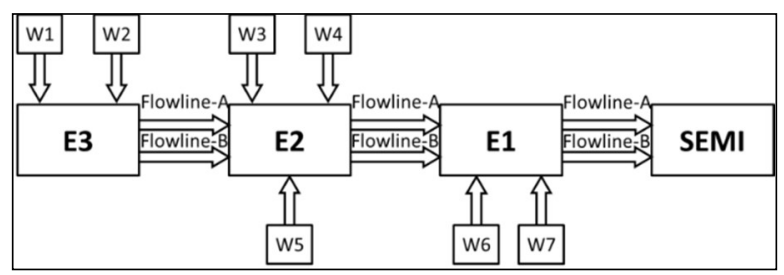

Figure 1. Schematic diagram of SPS development in target gas field

When hydrate is generated in the subsea pipeline and SPS will block pipelines and affect production, depressurization operation should be carried out on the platform to reduce the operating pressure in the subsea pipeline and make it lower than the hydrate dissolution pressure, so as to ensure the safety of production and operation.

\section{Depressurization process}

Hydrate formed in gas field is a kind of appearance and mechanical properties are similar to ice substance, which is generated by methane, ethane, propane, nitrogen, carbon dioxide, hydrogen sulfide and other gas composition with water under high pressure and low temperature conditions, it will reduce the flow of the pipeline area, or even blocking pipe, and possibly as highspeed flow of gas, damage to the valve in the pipeline, elbow and other parts[3]. After hydrate formation, domestic and foreign projects take remedies such as depressurization, methanol injection and heating. In the process of depressurization, in order to prevent the pressure difference between the two sides of the hydrate from being too high and causing danger in the high-speed operation of the pipeline, the pressure on both sides of the hydrate should be relieved at the same time. For this deepwater project in the South China Sea, the blowdown valve at the outlet of the double sea pipe can be released at the same time.

The platform outlet valve is closed, and the SPS continues to produce until the subsea tree reaches the shut-off pressure. At this time, the pressure corresponding to the outlet of the subsea pipe is 308 bar $(1 \mathrm{bar}=105 \mathrm{pa})$, which is the initial discharge pressure. The high-pressure production fluid in the subsea pipeline is discharged through the blowdown valve at the outlet of the subsea pipeline on the platform, and the discharged gas goes into

\footnotetext{
* Corresponding author: wangxy138@ cooec.com.cn
} 
the flare system for processing. The discharged lowtemperature fluid goes into the flare dispensing tank for storage and is sent back to the production process by booster pump. HP flare knock-out drum (TS-V-3401) min design temperature is $-99^{\circ} \mathrm{C}$, surge volume is $10 \mathrm{~m} 3$, but HP flare K.O drum pumps (TS-P-3401A/B) min design temperature is ambient temperature (AMB). The discharged low-temperature fluid can be heated to AMB by the electric heater (TS-EH-3401) in the tank and transported to the process flow. The processing capacity of SEMI platform flare system is $1176 \times 104 \mathrm{Sm} 3 / \mathrm{d}$. the maximum gas volume during pressure depressurization should not exceed the processing capacity of flare. All parameters in the depressurization process should meet the requirements of the above design parameters[4]. The depressurization process of the subsea pipeline is shown in Figure 2.

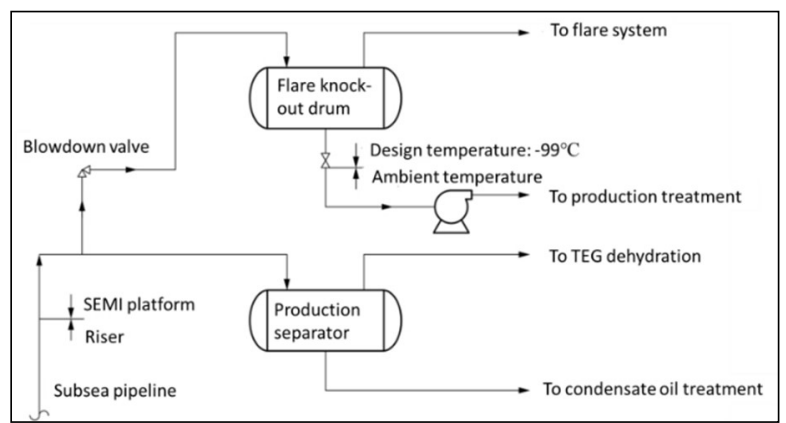

Figure 2. The depressurization process of the subsea pipeline

\section{Simulation method}

The initial condition for flowline blowdown was obtained with the integrated wellbore and flowline simulation model. The valves at flowline outlets were closed while the subsea chokes were kept the original opening. When equilibrium of system was established, the pressure at subsea wellheads reached the Shut-In Tubing Head Pressure. The subsea chokes were subsequently closed.

The reservoir gas composition of Year 2020 was used for the minimum temperature analysis, and higher gas system would result in higher drop in temperature. The flowing conditions were simulated with all production forecast flowrates. Consequently, the predicted minimum temperature is more conservative (lower), and the predicted depressurization time is shorter than those with production forecast flowrates.

The back pressure at the outlet of the blowdown valves was assumed to be 3 bar. Two blowdown cases were performed for the performed for the blowdown valve size of 0.5 and 1 inches.

\section{Simulation results with target gas field flowlines}

During the depressurization operation, the low temperature fluid will be carried out by gas from subsea pipeline into the flare knock-out drum storage, because of the booster pump and the production processing designed for $\mathrm{AMB}$, discharged low temperature fluid cannot be pump directly into the production processing system for treatment. The liquid must be stored in the knock-out drum to heat up until its temperature increases to AMB, when it can be pumped to the production processing system for treatment. According to the requirements of this working condition, if the conventional direct discharge method is adopted, the storage capacity of the knock-out drum will be $47.2 \mathrm{~m} 3$ at a minimum, which is much larger than the current surge volume of $10 \mathrm{~m} 3$. Therefore, based on the direct depressurization simulation of conventional projects, the multi-stage depressurization is creatively proposed. The surge volume of the flare knock-out drum is taken as the limit condition, and the pressure of the subsea pipeline is reduced by multi stage depressurization, so as to provide the operator with enough time for low temperature fluid treatment, that is, to dissolve the hydrate generated. Thus, the operation problems caused by the normal temperature design of the booster pump can be avoided.

The simulation results for depressurization of target gas field flowlines in Year 2020 with 0.5 inch diameter blowdown valves are as follows.

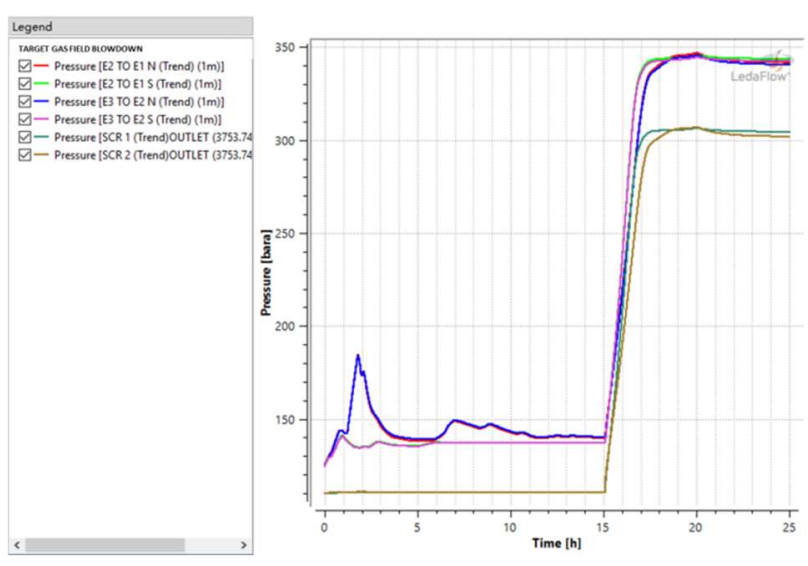

Figure 3. Pressure at target gas field subsea wellheads and flowline outlet prior to depressurization
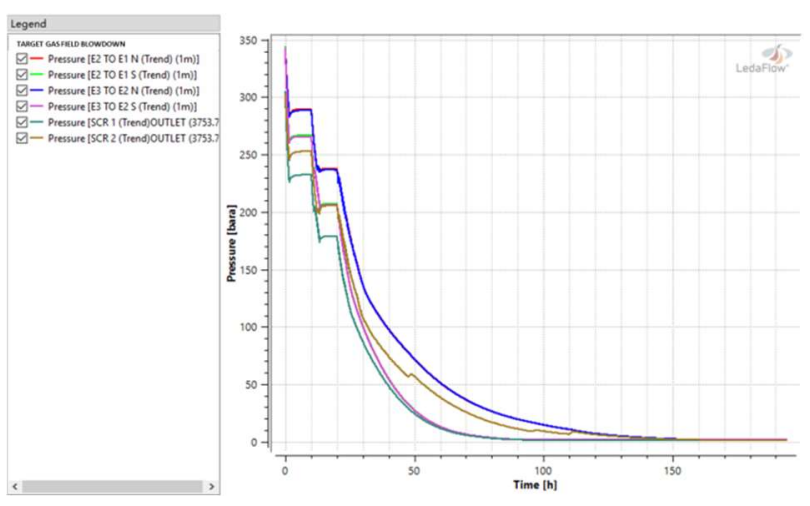

Figure 4. Flowline pressure during depressurization of target gas field subsea production system $\left(0.5^{\prime}\right.$ ') 

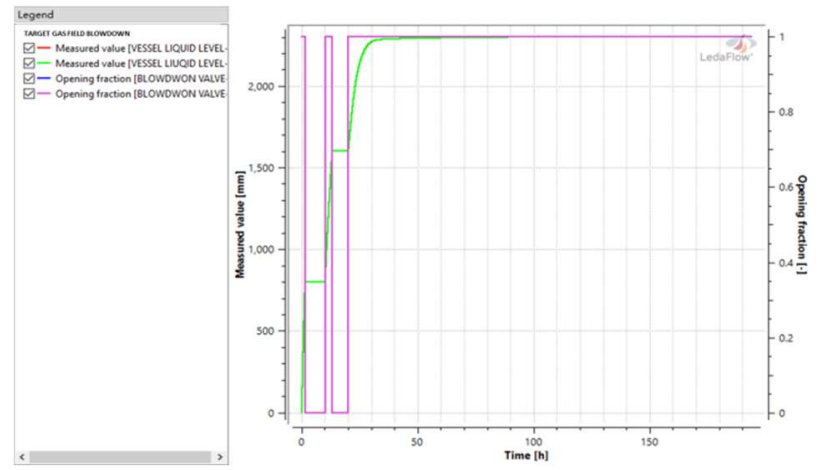

Figure 5. Volume of low-temperature liquid from flowlines and open/close status of valves during depressurization of target gas field subsea production system (0.5”)
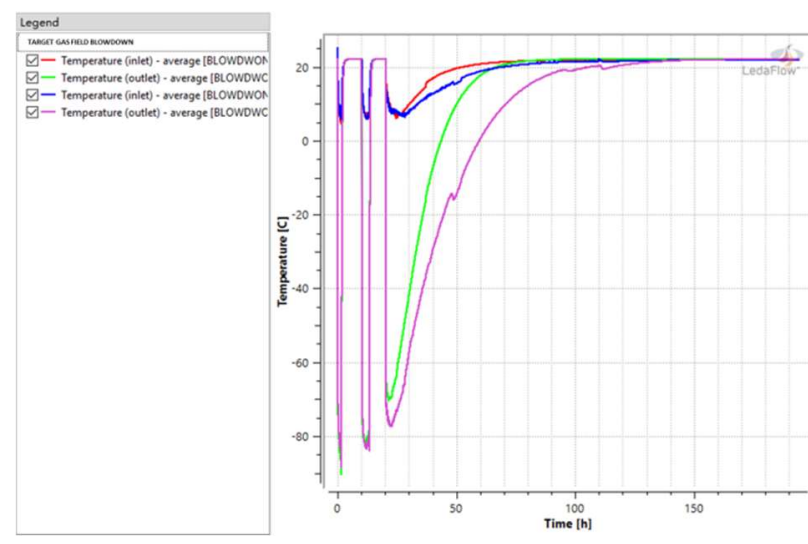

Figure 6. Low temperature during depressurization of target gas field subsea production system (0.5")

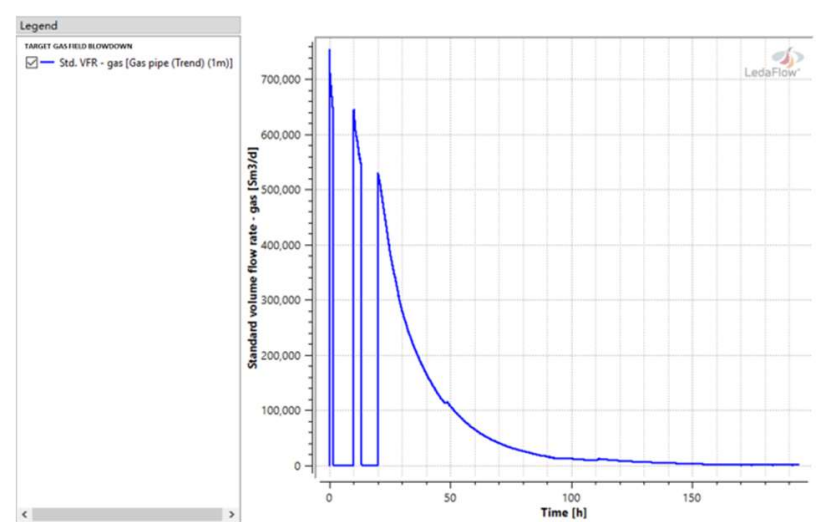

Figure 7. Standard condition gas flowrate during depressurization of target gas field subsea system $\left(0.5^{\prime \prime}\right)$

It can be seen from Figure 3 to Figure 7, when 0.5 inch blowdown valve was used for depressurization of target gas field flowlines in 2020, the flowline outlet pressure was reduced from 304 bar to 232 bar during the first stage of depressurization. The E3-E2 N \& E2-E1 N flowline inlet pressures were reduced from 341 bar to 289 bar. During the second stage of depressurization, the flowline outlet pressure was reduced to 179 bar, and the E3-E2 N \& E2-E1 N flowline inlet pressures were reduced 237 bar. During the third stage of depressurization, the flowline outlet pressure was reduced to 3 bar, and the E3-E2 \& E2E1 flowline inlet pressures were reduced 3.4 bar. It took about 139.2 hours for the flowline outlet pressure to reduce to the specified back pressure.

During the first stage depressurization, the low temperature liquid from the flowlines reached the volume of $10 \mathrm{~m}^{3}$ in 1.5 hours, and reached the volume of $10 \mathrm{~m}^{3}$ in 3.4 hours during the second stage. During the third stage, the volume of low temperature liquid stopped increasing after reaching $8.9 \mathrm{~m}^{3}$. Therefore, the total volume of low temperature liquid from all stages of depressurization was $28.9 \mathrm{~m}^{3}$.

The lowest temperature downstream of the blowdown valve was $-90.5^{\circ} \mathrm{C}$ during the first stage depressurization, $-84.5^{\circ} \mathrm{C}$ during the second stage depressurization and $77.3^{\circ} \mathrm{C}$ during the third stage depressurization, all within the low temperature design limits for the piping downstream of the blowdown valve and the knock-out drum of the high pressure flare system.

The maximum gas flowrate at the outlet of the blowdown valve was $75.3 \times 10^{4} \mathrm{Sm}^{3} / d$ during the first stage, $64.4 \times 10^{4}$ $\mathrm{Sm}^{3} / \mathrm{d}$ during the second stage and $53.1 \times 10^{4} \mathrm{Sm}^{3} / \mathrm{d}$ during the third stage. Since the flare system on the SEMI platform is design for $1176 \times 10^{4} \mathrm{Sm}^{3} / \mathrm{d}$, the gas flare during depressurization is within the flare system capacity.

The simulation results for depressurization of target gas field flowlines in Year 2020 with 1 inch diameter blowdown valves are as follows.

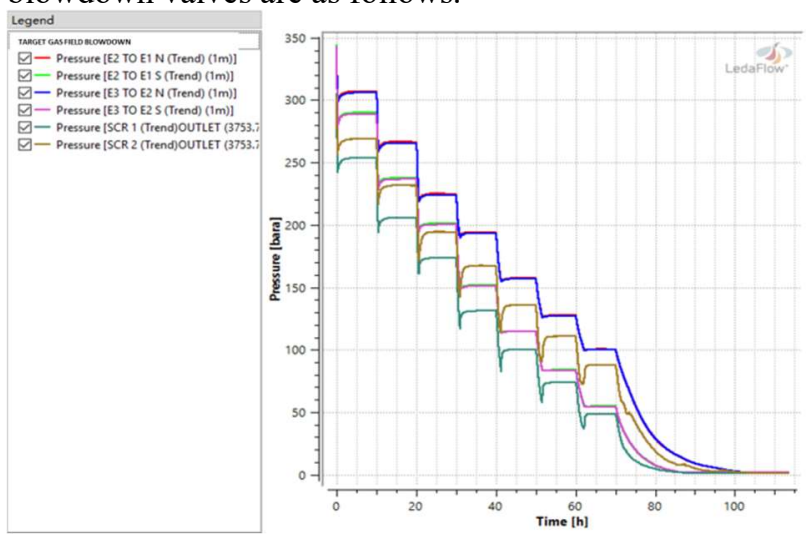

Figure 8. Flowline pressure during depressurization of target gas field subsea production system (1")

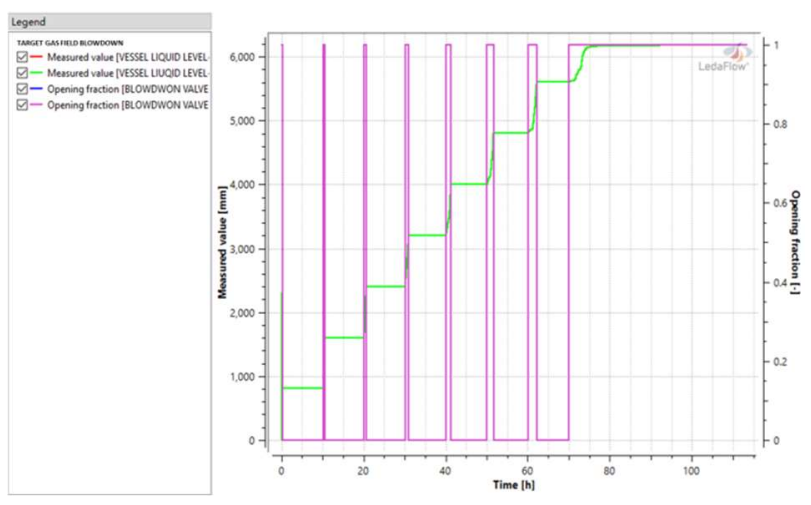

Figure 9. Volume of low-temperature liquid from flowlines and open/close status of valves during depressurization of target gas field subsea production system (1") 

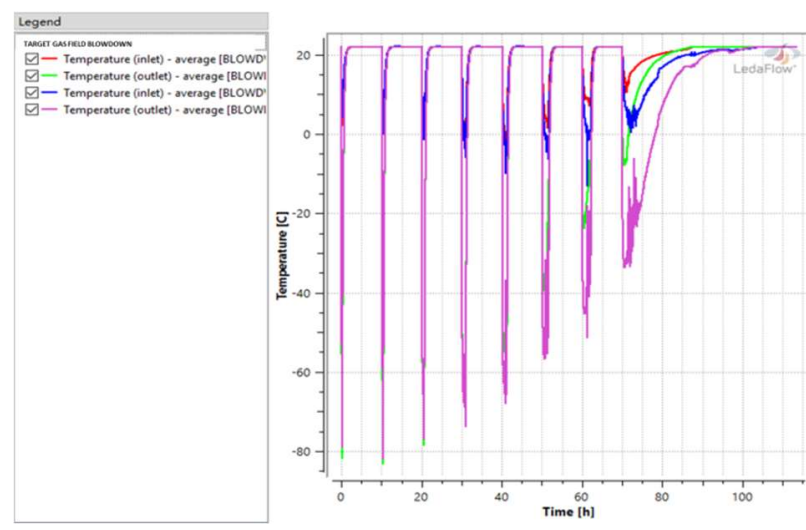

Figure 10. Low temperature during depressurization of target gas field subsea production system (1")
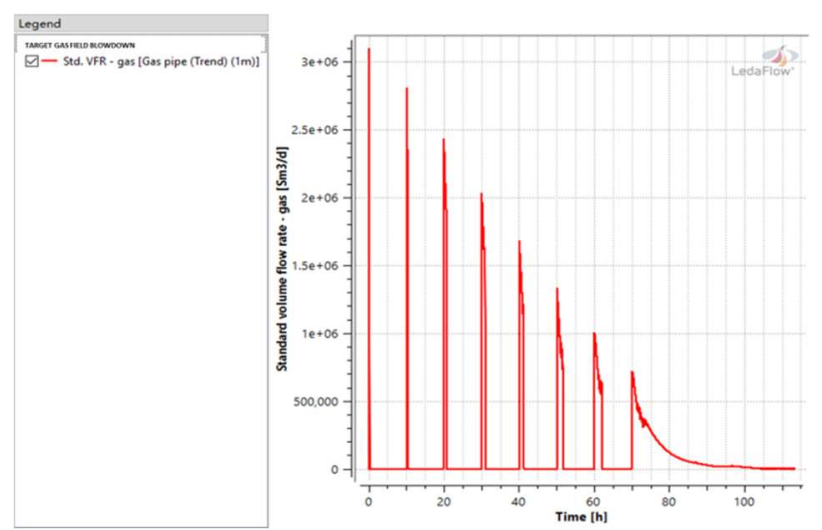

Figure 11. Standard condition gas flowrate during depressurization of target gas field subsea system (1")

It can be seen from Figure 8 to Figure 11, when 1 inch blowdown valve was used for depressurization of target gas field flowline in 2020, the flowline outlet pressure was reduced from 304 bar to 254 bar, and it takes 8 stages to reduce to 3 bar. The E3-E2 N \& E2-E1 N flowline inlet pressures were reduced from 334 bar to 307 bar and takes 8 stages to reduce to 3.4 bar. It took about 91.2 hours for the flowline pressure to reduce to the specified back pressure.

During the first stage depressurization, the low temperature liquid from the flowlines reached the volume of $10 \mathrm{~m}^{3}$ in 0.28 hours, and the last stage, the volume of low temperature liquid stopped increasing after reaching $7.7 \mathrm{~m}^{3}$. Therefore, the total volume of low temperature liquid from all stages of depressurization was $77.7 \mathrm{~m}^{3}$.

The lowest temperature downstream of the blowdown valve was $-83.2^{\circ} \mathrm{C}$ during the all stages depressurization, all within the low temperature design limits for the piping downstream of the blowdown valve and the knock-out drum of the high pressure flare system.

The maximum gas flowrate at the outlet of the blowdown valve was $310 \times 10^{4} \mathrm{Sm}^{3} / \mathrm{d}$ during the first stage, the following stages are 281, 243, 203, 168, 133, 100 and $72 \times 10^{4} \mathrm{Sm}^{3} / \mathrm{d}$, respectively. Since the flare system on the SEMI platform is design for $1176 \times 10^{4} \mathrm{Sm}^{3} / \mathrm{d}$, the gas flare during depressurization is within the flare system capacity.
Table 1 summarizes the simulation results for depressurization of target gas field with 0.5 inch and 1 inch blowdown valves.

Table 1. Summary of target gas field depressurization simulation results

\begin{tabular}{|c|c|c|c|}
\hline BDV Size & in & 0.5 & 1 \\
\hline $\begin{array}{c}\text { Number of } \\
\text { depressurization }\end{array}$ & / & 3 & 8 \\
\hline $\begin{array}{l}\text { Total Volume of low } \\
\text { temperature liquid } \\
\text { form flowlines during } \\
\text { depressurization }\end{array}$ & $\mathrm{m}^{3}$ & 28.9 & 77.7 \\
\hline $\begin{array}{c}\text { Minimum temperature } \\
\text { at the outlet of } \\
\text { blowdown valve }\end{array}$ & ${ }^{\circ} \mathrm{C}$ & -90.5 & -83.2 \\
\hline $\begin{array}{c}\text { Maximum gas flowrate } \\
\text { at the outlet of } \\
\text { blowdown valve }\end{array}$ & $\begin{array}{c}10^{4} \\
\mathrm{Sm}^{3} / \mathrm{d}\end{array}$ & 75.3 & 310 \\
\hline $\begin{array}{l}\text { Time for the flowline } \\
\text { outlet to be } \\
\text { depressurization to } 10 \\
\text { bar }\end{array}$ & $\mathrm{h}$ & 90.8 & 83.3 \\
\hline $\begin{array}{c}\text { Time for the flowline } \\
\text { outlet to be } \\
\text { depressurization to } 3 \\
\text { bar }\end{array}$ & $\mathrm{h}$ & 139.2 & 91.2 \\
\hline $\begin{array}{l}\text { Minimum temperature } \\
\text { at the upstream of } \\
\text { blowdown valve }\end{array}$ & ${ }^{\circ} \mathrm{C}$ & 4.5 & -12.9 \\
\hline
\end{tabular}

From the above analysis results, 0.5 in and 1 in blowdown valve have their own advantages, and the operator can determine the size of the blowdown valve according to the concerned depressurization parameters.

\section{Conclusion}

In summary, the depressurization analysis for regular project, the high pressure fluid in the subsea pipeline is simulated with directly discharged by blowdown valve. Under the condition of the discharge gas flow does not exceed the processing capacity of the flare treatment, the low temperature flow does not exceed the capacity of the flare knock-out drum pump, and the low temperature at the outlet of the blowdown valve does not exceed the minimum design temperature of the depressurization system, then the appropriate size and time of the blowdown valve are determined. However, this method does not take into account the condition that the flare knock-out drum pump is designed at AMB, which cannot transport low temperature fluid in time, and the power of the heater in the flare knock-out drum does not meet the load requirements.

In the design process of the South China sea project, the multi stage depressurization concept was proposed innovatively. Under the condition of the flare knock-out drum surge volume, to provide operators with enough time for handing low temperature fluid. The contradiction 
between low temperature fluid transport and the minimum design temperature of booster pump or other equipment was well solved, which provided a reference for the development of similar projects in the future.

\section{References}

1. L.Song, S.G. Yang, B.L. Liu, Ocean Development and Management, 30, 06 (2013)

2. Z.D. Huang, X.M. Li, R.J. Shen, J. Luo, N. Li, China Offshor Oil and Gas, 26, 01 (2014)

3. W.F. Chen, P.P. Ju, P.L. Liu, H. Zhang, X.Y. Zhou, T. Deng, Ocean Engineering Equipment and Technology, 7, 02 (2020)

4. Transient Simulation Study Report for Target Gas Field Flowlines, (2018) 